\title{
Management system for the development of industrial parks to increase the competitiveness of resident enterprises
}

\author{
Vadim Krivorotov $^{1}$, Evgeniy Tikhanov ${ }^{1}$, Aleksandr Tarasenko $^{2}$, Petr Chepur ${ }^{2}$, and Alesya \\ Gruchenkova ${ }^{3, *}$ \\ ${ }^{1}$ Ural Federal University named after the first President of Russia B. N. Yeltsin, 620002 Mira Street \\ 19, Russia \\ ${ }^{2}$ Industrial University of Tyumen, 625000 Volodarskogo Street 38, Russia \\ ${ }^{3}$ Surgut Oil and Gas Institute, 628405 Entuziastov Street 38, Russia
}

\begin{abstract}
Industrial parks are the most dynamically developing, universal and effective format for the organization of investment sites, allowing enterprises to create modern competitive production at minimal costs and in optimal terms. In this regard, a relevant problem is ensuring further development of such investment sites aimed at improving the competitive positions of business entities operating on their territory. The authors proposed an algorithm for the formation of a management system for the development of an industrial park to increase the competitiveness of resident enterprises, which is based on establishing the relationship between the quantitative assessment of the level of competitiveness of residents of an industrial park and the key indicators of its activities. Approbation of the proposed system is presented for the purpose of forming a program for the development of the industrial park "Chemical Park "Tagil", operating in the Sverdlovsk region.
\end{abstract}

\section{Introduction}

Today, industrial parks are the most dynamically developing, universal and effective format for the organization of investment sites, allowing enterprises to create modern competitive production at minimal costs and in optimal terms [1-6]. Enterprises that place production on the territory of industrial parks receive a whole range of benefits, including the reduction of time and financial costs for the organization of production, the proximity of markets and labor resources, an advantageous location in relation to transport arteries, targeted administrative and financial support to residents of industrial parks by the state $[7,8]$.

Considering that increasing the competitiveness of the domestic industry is one of the main priorities of the development of the national economy, and industrial parks ensure the creation of favorable conditions for increasing the competitiveness of enterprises, the problem of ensuring further development of such investment sites aimed at improving the

\footnotetext{
*Corresponding author: alesya2010-11@yandex.ru
} 
competitive positions of business entities operating on their territory has become most relevant.

\section{Methods}

The management system for the development of industrial parks to increase the competitiveness of resident enterprises, proposed by the authors, is based on establishing the relationship between the quantitative assessment of the level of competitiveness of residents of an industrial park and the key indicators of its activities. To ensure the practical application of the system being developed during modeling of the relationship between the indicators mentioned, the following requirements must be met in aggregate:

1. The functional relationship between the level of competitiveness of the residents of an industrial park and the performance indicators of the site should be established using a widely used mathematical apparatus.

2. The initial data used in the calculations should be representative, that is, covering a sufficiently long-time interval.

3. The final assessment is that of the level of competitiveness not of an individual resident of an industrial park, but of a group of anchor residents, which ensures the formation of the most objective model and allows the subsequent development of a set of measures aimed at increasing the competitiveness of a group of the largest enterprises.

The algorithm for constructing a model of the relationship between the indicators of the industrial park activity and the level of competitiveness of its residents is presented in Figure 1 and includes the following steps:

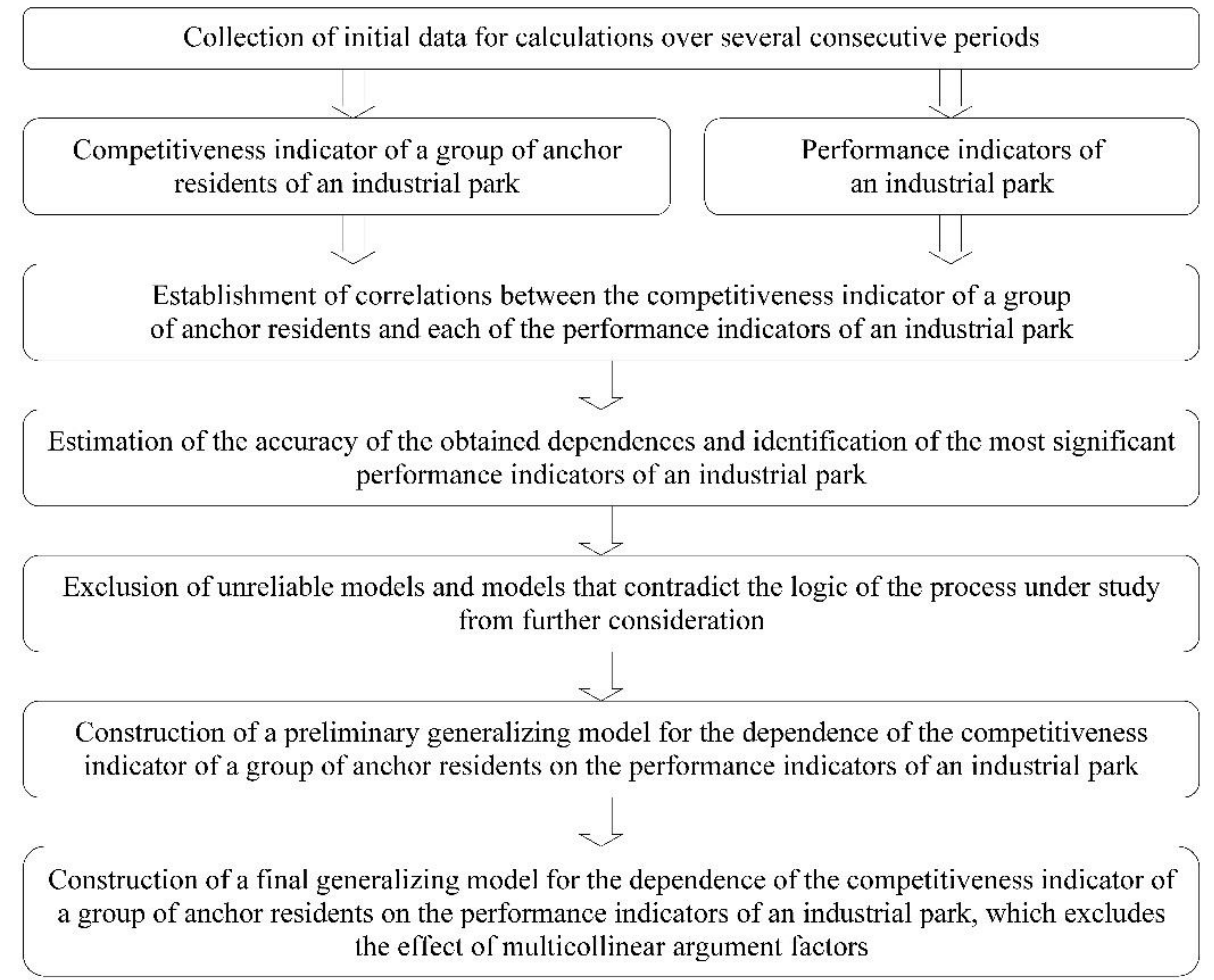

Fig. 1. Algorithm for constructing a model for the dependence of the competitiveness indicator of a group of anchor residents on the performance indicators of an industrial park. 
1. Collection of initial data for calculations over several consecutive periods. To ensure the representativeness of the data, the calculation of the competitiveness indicator of a group of anchor residents of an industrial park and the performance indicators of the industrial park is carried out over not less than five similar time periods.

2. Establishment of correlations between the competitiveness indicator of a group of anchor residents and each of the performance indicators of an industrial park.

The method of correlation-regression analysis [9, 10], which is the main one in the practice of studying the relations between various phenomena, processes and their characteristic quantities, is based on modeling the dependence of the considered indicators. Correlation-regression models allow us to establish the functional relationship and the degree of impact of the industrial park activity indicators on the level of competitiveness of the site residents. The system of models, formed at the initial stage, characterizing the dependence of the competitiveness indicator of a group of anchor residents on each of the performance indicators of the industrial park is as follows:

$$
K=f\left(P_{1}, P_{2}, \ldots, P_{\mathrm{n}}\right)
$$

where $\mathrm{K}$ - value of the competitiveness indicator of the group of anchor residents of the industrial park calculated depending on the values of performance indicators of the industrial park;

$\mathrm{P}_{1}, \mathrm{P}_{2}, \ldots, \mathrm{P}_{\mathrm{n}}-$ values of industrial park performance indicators.

At this stage, the choice is made of the kind of mathematical function that determines the cause-effect relationship between the indicators studied, as well as the parameters of the function that determine tightness and direction of the relationship between the values.

3. Estimation of the accuracy of the obtained dependences, which involves analysis of the reliability of the regression equation, regression coefficients, relationship strength, approximation errors and other parameters, as well as identification of the most significant performance indicators of an industrial park.

4. Exclusion of unreliable models and models that contradict the logic of the process under study from further consideration.

5. Construction of a preliminary generalizing model for the dependence of the competitiveness indicator of a group of anchor residents on the performance indicators of an industrial park, which includes the entire set of the selected indicators.

6. Construction of a final generalizing model for the dependence of the competitiveness indicator of a group of anchor residents on the performance indicators of an industrial park, which excludes the effect of multicollinear argument factors. At this stage, a number of indicators that have a strong correlation with other indicators included in the model are removed from the model, which increases the practical applicability of the final model of the sought dependence. In the future, the generalizing model of dependence of the level of competitiveness of the residents on the indicators of the industrial park activity can serve as a basic tool for the development of management impacts aimed at improving the activities of the industrial park.

The proposed methodological apparatus allows forming a management system for the development of an industrial park, aimed at increasing the competitiveness of enterprises operating on its territory. The main stages of its construction are presented in Figure 2. The proposed algorithm for the formation of a management system for the development of an industrial park assumes:

1. Calculation of the performance indicators of an industrial park for a certain time period $[11,12,13]$.

2. Calculation of the competitiveness indicator of residents of an industrial park over the same time period [14-16] and identification of indicators of performance of the industrial 
park based on the correlation-regression analysis, which have the greatest impact on the competitiveness level of the anchor residents of the industrial park.

3. Calculation of the performance indicators of competitor industrial parks and identification of the performance indicators of an industrial park in question requiring improvement.

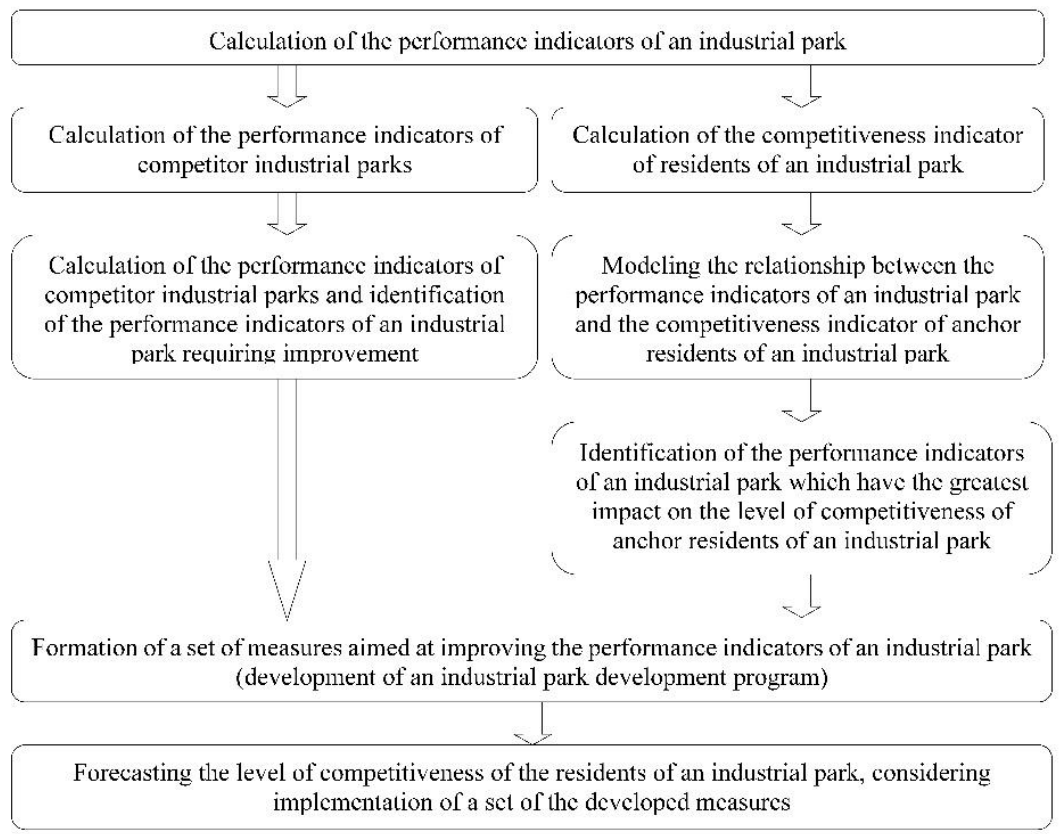

Fig. 2. Algorithm for the formation of a management system for the development of an industrial park.

4. Formation of a program for the development of an industrial park, which includes a set of measures aimed at improving the performance of the site [17-19].

In addition, the obtained generalizing model of dependence of the competitiveness indicator of a group of anchor residents on the performance indicators of an industrial park can be used to obtain predictive estimates of the level of competitiveness of enterprises operating on the territory of an industrial park when developing and planning activities under the industrial park development program.

\section{Results and Discussion}

Thus, the proposed management system for the development of an industrial park is a practical tool that can be used by management companies to form a program for future development of an industrial park and create favorable conditions for the activities of resident enterprises on its territory, which ultimately will enhance the investment attractiveness of the site and attract new companies to the industrial park.

The proposed system was used to solve the practical problem associated with the development of the program for the development of the industrial park "Chemical Park "Tagil", operating in the Sverdlovsk region. The project is a combination of horizontally and vertically integrated chemical industries, characterized by high standards of environmental safety and located in close proximity to the resource base, accessible energy and labor resources, multidirectional markets. The obtained dependence of the competitiveness 
indicator of the anchor residents of the industrial park "Chemical Park "Tagil" on the key indicators of its activities has the form:

$$
K=0.0002 \cdot P_{\mathrm{ip}}+0.0363 \cdot P_{\mathrm{s}}+P_{\mathrm{lol}}-2.17
$$

where $\mathrm{K}$ - value of the competitiveness indicator of the group of anchor residents of the industrial park "Chemical Park "Tagil";

$\mathrm{P}_{\mathrm{lol}}$ - average cost of lease of land on the territory of an industrial park;

$\mathrm{P}_{\mathrm{s}}-$ level of specialization of an industrial park in certain types of activities;

$\mathrm{P}_{\mathrm{ip}}$ - level of innovation of goods produced on the territory of an industrial park.

The analysis shows that such indicators as the cost of lease of land on the site, the level of specialization of the industrial park and the level of innovation of goods produced on the territory of the industrial park have the strongest impact on the level of competitiveness of the residents of the industrial park "Chemical Park "Tagil". At the same time, the competitiveness of the residents is influenced by the performance indicators of the management company, the breadth and diversity of the range of services provided to residents, the amount of capital investments in the development of the industrial park and the level of tax burden on the territory of the industrial park.

Proceeding from this, the authors propose a three-level program for the development of an industrial park (Figure 3), in which the basic strategic priorities for the development of the project are the expansion of the range of services provided to resident enterprises and the activation of the creation of a specialized technological and engineering infrastructure necessary for residents to conduct the production and development of innovative activities on the territory of an industrial park.

Level 1

Expanded set of specialized additional services provided to the residents Increased investment in the development of the engineering and technological infrastructure of the site

Level 2

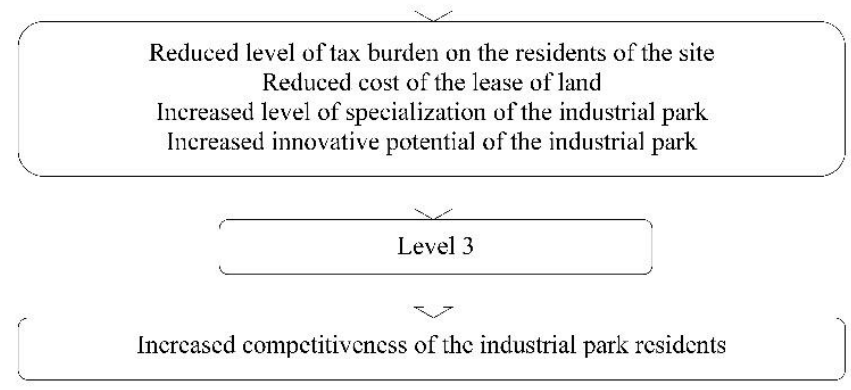

Fig. 3. Structure of the program for the development of the industrial park "Chemical Park "Tagil", aimed at increasing the competitiveness of its residents.

\section{Conclusions}

As a result of the work, the main features of industrial parks were identified, which make it possible to consider them as the most universal and effective format for the organization of 
investment sites. A basis for the proposed management system for the development of industrial parks to increase the competitiveness of resident enterprises is establishing the relationship between the quantitative assessment of the level of competitiveness of residents of an industrial park and the key indicators of its activities.

An algorithm is proposed for constructing a model for the dependence of the competitiveness indicator of a group of anchor residents on the performance of an industrial park. Also, an algorithm is developed for the formation of a management system for the development of an industrial park to increase the competitiveness of resident enterprises. Based on the proposed methodology a program is developed for the development of the industrial park "Chemical Park "Tagil", operating in the Sverdlovsk region.

\section{References}

1. V.A. Bykov, T.G. Filosofa, Konkurentsiya. Innovatsii. Konkurentosposobnost' (Uniti, Moscow, 2008)

2. A.L. Denisova, N.V. Ylyakhin, Upravlenie konkurentosposobnost'yu promyshlennogo predpriyatiya: aspekty kachestva (Tambov state technical University, Tambov, 2006)

3. T.Yu. Ivanova, V.I. Prikhodko, Teoriya organizatsii (KnoRus, Moscow, 2010)

4. V.V. Krivirotov, A.V. Kalina, E.A. Tikhanov, S.E. Erypalov, Vestnik of the Ural Fed. Univ. 2, 61-74 (2014)

5. V.V. Krivirotov, Metodologiya formirovaniya mekhanizma upravleniya konkurentosposobnost'yu predpriyatiya (Ural State Technical University, Yekaterinburg, 2007)

6. I.B. Gurkov, Innovatsionnoe razvitie $i$ konkurentosposobnost': ocherki razvitiya rossiyskikh predpriyatiy (Teis, Moscow, 2012)

7. V.V. Krivirotov, A.V. Kalina, V.D. Tretyakov, E.A. Tikhanov, K.E. Parfenov, Vestnik of the Ural Fed. Univ. 4, 61-76 (2013)

8. V.L. Belousov, Analiz konkurentosposobnosti firmy (Marketing in Russia and abroad, Moscow, 2007)

9. G.A. Sokolov. R.V. Sagitov, Vvedenie $v$ regressionnyy analiz $i$ planirovanie regressionnykh eksperimentov $v$ ekonomike (INFRA-M, Moscow, 2010)

10. B.V. Shabbat, Vvedenie v kompleksnyy analiz (Moscow, 2010)

11. V.V. Krivirotov, I.V. Ershova, I.S. Belik, Konkurentosposobnost' sotsial'noekonomicheskikh sistem: vyzovy novogo vremeni (Economika, Moscow, 2014)

12. L.G. Iogman, M.A. Gusakov, The Region's Econ. 4, 85-94 (2007)

13. E.I. Mazilkina, G.G. Panichkina, Upravlenie konkurentosposobnost'yu (Omega-L, Moscow, 2007)

14. E.M. Korotkov, Menedzhment (INFRA-M, Moscow, 2010)

15. O.V. Savinova, M.A. Istrashkina, Econ. of educ. 5, 135-152 (2012)

16. V.V. Krivirotov, A.V. Kalina, T.V Matveeva, A.Yu. Bayranshin, Povyshenie konkurentosposobnosti sovremennykh rossiyskikh territorial'no-proizvodstvennykh kompleksov (Ural State Technical University, Yekaterinburg, 2013)

17. A.A. Kuzubov, Fundam. Res. 12(4), 801-805 (2015)

18. A.V. Postrelova, M.C. Markin, Young Sci. 6, 398-402 (2013)

19. M.R. Petritchenko, S.A. Subbotina, F.F. Khairutdinova, et.al. Magazine of Civil Engineering 73, 40-48 (2017), doi:10.18720/MCE.73.4 